\title{
TEMPLE USPENIJA OF THE VIRGIN AS A MEANS OF IN- FLUENCE ON THE FORMATION OF NATIONAL IDENTITIES OF UKRAINIANS
}

\author{
Lyudmyla Radchenko ${ }^{1}$, Vladimir Pobyvanets ${ }^{2}$, Vitaliy Pobyvanets ${ }^{3}$ \\ ${ }^{1}$ Department of Tourism and Social Humanities Sciences, Kharkiv College of Trade and Economics, Kyiv National University of Trade \\ and Economics, Kharkiv, Ukraine \\ kharkiv@htek.com.ua \\ ORCID: https://orcid.org/0000-0002-2514-7549 \\ ${ }^{2}$ Writer, Winner of Literary Prizes named after M. Masla and I. Drobny, Zolotonosha, Cherkasy region, Ukraine \\ agrozolot@gmail.com \\ ORCID: https://orcid.org/0000-0001-6503-0380 \\ ${ }^{3}$ Doctor of the Highest Qualification Category, Member of the National Union of Local Historians of Ukraine, Laureate of the M. Ponoma- \\ renko Local History Prize, Zolotonosha, Cherkasy region, Ukraine \\ pobyvanez05@ukr.net \\ ORCID: https://orcid.org/0000-0001-6089-3654
}

ARTICLE INFO

Article history:

Received date 26.03.2021

Accepted date 27.03.2021

Published date 30.04.2021

Section:

History

D O I

10.21303/2313-8416.2021.001809

KEYWORDS

Temple Uspenija of the Virgin

national identity

Orthodox Christian

spirituality

religiosity

\section{ABSTRACT}

Based on the analysis of the development of Christianity on the example of Zolotonosha (Left Bank Dnieper) the history of Orthodox churches is studied. The place of the Zolotonosha Assumption Cathedral in the spiritual and moral life of the Ukrainian people is substantiated. The role of the church in increasing the social activation of the Orthodox Christian personality and social development of Zolotonosha region is proved.

The object of research: the Temple Uspenija of the Virgin as a historical, architectural and spiritual monument of Ukraine, its impact on public consciousness in the formation of the national identity of Ukrainians.

Investigated problem: the development of Ukrainian Orthodoxy on the example of Zolotonosha as an effective means of forming the national identity of Ukrainians and a significant factor in the democratization of society on the basis of Christian values, which increases the morality and spirituality of the people.

The main scientific results: the integral history of orthodox churches of Zolotonosha region is analyzed on the basis of data of researchers and local historians, archival church documents. The place of Zolotonosha sanctuary as one of the largest temples of Central Ukraine in the formation of the spiritual culture of the Ukrainian people is substantiated. The role of the Holy Dormition Cathedral in increasing the social activation of the Orthodox Christian personality and social development of Zolotonosha region during its history is revealed.

The area of practical use of the research results: the results of the study can be used by public administration and local government in determining public policy in the field of religion, mechanisms for solving its current problems, during the development and teaching of courses on public administration, history of religion, world history and history of Ukraine. Innovative technological product: on the basis of fragmentary data of researchers and local historians, numerous archival church materials and documents, some of which are introduced into scientific circulation for the first time, a significant gap in ideas about the holistic picture of the history of Zolotonosha Assumption Cathedral as a historical, architectural and spiritual monument of Ukraine was filled for 70 years had been prohibited. The place of the Temple Uspenija of the Virgin in the spiritual and moral life of an Orthodox Christian is substantiated. The role of the Zolotonosha Church in the formation of the national identity of Ukrainians is highlighted.

Scope of the innovative technological product: theoretical research, the practice of forming the national identity of Ukrainians, a means of influencing religiosity to increase the morality and spirituality of people, the implementation and improvement of the system of state regulation by religious organizations.

(C) The Author(s) 2021. This is an open access article under the Creative Commons CC BY license

\section{Introduction}

\section{1. The object of research}

Temple Uspenija of the Virgin Mary as a historical, architectural and spiritual monument of Ukraine, its impact on public consciousness in the formation of the national identity of Ukrainians. 


\section{2. Problem description}

In the current conditions of Ukraine's independence, socio-economic and political-ideological crises and pandemics have provoked social and spiritual apathy of the vast majority of the population.

A number of works reveal the development of Ukrainian Orthodoxy as an effective means of influencing the public consciousness [1] for the formation of the national identity of Ukrainians $[2,3]$, the democratization of society on the basis of Christian values [4]. The religiosity of modern Ukrainian society, which has a tendency to grow, is designed to increase the morality and spirituality of Orthodox Christians [5], to form a specific Ukrainian soul, conscience, mentality [6].

A number of researchers consider the holistic picture of the history of the Assumption Cathedral in Zolotonosha as a historical, architectural and spiritual monument of Ukraine [7-9], substantiate the place of the Assumption Cathedral in the spiritual and moral life of Orthodox Christians $[2,4]$, highlight the role of the Zolotonosha Church. in the formation of the national identity of Ukrainians [1, 2].

Therefore, an effective means of influencing the public consciousness in the formation of the national identity of Ukrainians, the democratization of society on the basis of Christian values is the development of Ukrainian Orthodoxy. The religiosity of modern Ukrainian society, which has a tendency to grow, is designed to increase the morality and spirituality of Orthodox Christians, to form a specific Ukrainian soul, conscience, mentality.

Today it deserves further research and study of the historical role of churches, the spiritual development of the Orthodox Christian at the local level, in our case - on the example of the Temple Uspenija of the Virgin in Zolotonosha Left-Bank Dnieper.

\section{3. Suggested solution to the problem}

The problem of forming the national identity of Ukrainians, raising public consciousness, morality and spirituality of Orthodox Christians, democratization of society on the basis of Christian values can be solved by studying the analysis and generalization of the historical past of the Ukrainian church, the spiritual life of Orthodox Christians at the local level Zolotonosha.

The purpose of the study is to substantiate the holistic history of Orthodox churches in Zolotonosha, the place and role of Zolotonosha Holy Dormition Cathedral, its impact on increasing the social activation of Orthodox Christians in the formation of national identity of Ukrainians.

\section{Materials and Methods}

The methodological basis of the study is a system of scientific principles, approaches and methods of cognition, aimed at a comprehensive study of socio-political phenomena, facts, events, objective reproduction and analysis of historical realities. The work is based on the fundamental principles of scientific knowledge: historicism, systematics, comprehensiveness, alternativeness.

This allowed to reveal the place, role and significance of the Temple Uspenija of the Virgin as an effective means of influencing the formation of the national identity of Ukrainians.

\section{Results}

In the conditions of Ukraine's independence, socio-economic and political-ideological crises and pandemics have provoked social and spiritual apathy of the vast majority of the population. Today the church is able to play an important role in increasing the social activation of the individual. It is an essential factor in the democratization of society on the basis of Christian values, especially man, created in the image and likeness of God, catholicity, unity, solidarity, mercy and love.

The religiosity of modern Ukrainian society, according to sociological research, is $66 \%$ and almost reached the level of $1913(67 \%)$ is becoming increasingly visible phenomenon not only in private but also in public life, especially in the context of the war in the East, provoked by Russian aggression.

According to sociological research by the Razumkov Center, $71 \%$ of respondents believe that religion increases the morality and spirituality of people.

Orthodoxy in ancient times formed a specific soul, conscience, mentality, way of life of our ancestors.

That is why there is a need to study the development of the Orthodox Christian at the local level, in our case - on the example of Zolotonosha, in the Left Bank of the Dnieper. 
The church has always been an important means of influencing the public consciousness, the formation of the national identity of Ukrainians. Knowledge of the past of the Ukrainian Church will help to overcome artificial stereotypes imposed by Soviet ideology. Unfortunately, 70 years of research into the spiritual life of the Ukrainian people have been prohibited. During this time, a significant number of primary sources were lost, so achieving the goal set in preparation for writing the article was problematic.

On the basis of fragmentary data of a number of researchers and local historians, archival church documents it was possible to collect a complete picture of the history of the Assumption Cathedral in Zolotonosha. Let's consider the records of Pavel Alepsky to be an important mention of him, which M. Zharkykh quotes on his personal website based on the results of studying the description of the trip of Patriarch Macarius and Pavel Khalepsky (Alepsky) to Ukraine in 1654 and 1656.

Valuable information about the religious buildings of Zolotonosha and, in particular, the Church of the Assumption of the Blessed Virgin Mary is given in the work of M. Sagarda "The City of Zolotonosha and its holy temples". M. O Maksimovich also writes in his memoirs about visiting the Holy Dormition Church. On the basis of his research and his own archival research, the history of the churches of Zolotonosha was described by the famous local historian M. F. Ponomarenko. Some brief information about the Churches of Zolotonosha is obtained from the Encyclopedic Dictionary of Brockhaus and Efron. The clerical books of the Poltava diocese for 1902 and 1912 give an idea of the church buildings, church property, and most importantly - brought the names of the then clergy. The data given by T. Kolomensky testify to the material condition of the parishes.

In the initial stages of the formation of Soviet power, the so-called "renewal" had a negative effect on the monolithic nature of the church. The Holy Dormition Cathedral was divided. This is evidenced by the materials of the First Orthodox Council of the UAOC (1921) [5].

The idea of terror and repression of the new government in the thirties of the twentieth century, give materials collected by the Cherkasy Diocese in a collection edited by His Eminence Archbishop Sophrony of Cherkasy and Kaniv "Holy New Martyrs and Confessors of Cherkasy: Life, Feats, Sufferings" [10].

The newspaper Ukrainske Slovo, published in the Zolotonosha region during the Nazi occupation, recreates in its materials the history of worship services in the Temple Uspenija of the Virgin.

On the basis of archival materials collected in the Museum of Local Lore in Zolotonosha, it is possible to trace the difficult path of Ukrainian Orthodoxy in the postwar period.

Further study of the history of the Orthodox churches of Zolotonosha requires further search for primary sources to reproduce the whole picture.

Archdeacon Paul of Aleppo, son of Patriarch Macarius of Antioch, traveling with his father in 1652-1659 from Syria through Turkey, Romania, Ukraine, Russia in his memoirs for 1656 writes: "Then we drove another 4 miles and arrived in a town like this, the first named Zolotonosha with two churches, one of which is in honor of the Assumption of the Lady" [7].

This, in our opinion, is important in understanding the role of the Church of the Assumption of the Blessed Virgin Mary for the then Zolotonosha community. It is obvious that His Eminence Patriarch Macarius and his parishioners stopped near this church on the Kremenchug tract M. Sagarda, a well-known Ukrainian historian, theologian, bibliographer, author of fundamental works on the history of the church and Christian literature, wrote about the earlier existence of churches in his work "The City of Zolotonosha and its holy temples" in 1897, noting: "But this church building it was built on the site of an even older one perhaps the latter was not the first, because in the early years of the seventeenth century. The Church of the Assumption and St. Nicholas were already the center of a well-organized religious life" [2]. These two temples, located in the center of the city, securely protected by fortress walls, earthen ramparts, gates with drawbridges, served to meet the religious needs of citizens. M. Maksymovych and M. Ponomarenko speak about the construction of these churches, as evidenced by two tombstones. Now these stones are exhibits of the Zolotonosha Museum of Local Lore named after M. F. Ponomarenko. The parents of the Kosh Ataman of the Zaporizhzhia Army, a prominent political figure of the first half of the $18^{\text {th }}$ century, were buried near St. Nicholas Church, Ivan Malashevich, a native of the Zolotonosha Cossacks. He presented the Church with the Gospel of the Kyivan Press of 1733 with the following inscription: give in eternal times to the church of St. Nicholas of Zolotonosha" [1]. 
In the scientific letter of L. Nabok and O. Yurchenko "Church construction of Pereyaslav during the Hetman's time", published in the collection of materials of the scientific-practical conference "Cultural and religious development of the Hetmanate of the late seventeenth and early eighteenth centuries", it is stated in that years. Uncles of the Serbs in Zolotonosha build a church. At the entrance to Zolotonosha of the $19^{\text {th }}$ century, each traveler was greeted by the city cemetery with the Church of the Myrrh-Bearing Women on the Pereyaslav Road, and in front of it was the Jewish hut of the Zolotonosha wine ransom. This wooden church "in one connection with the same bell tower, cold...", built in 1865 without a single nail "at the expense of the 1st guild of the merchant Grigory Yunakov", was assigned to the Assumption Cathedral. Archival documents testify to the troubles associated with the church bells of the Myrrh-bearing Church. The decree of September 19, 1828 on the need to investigate the disappearance of the bells was sent to the acting charitable archpriest Samuel Navrotsky from the Poltava Spiritual Consistory.

As a result of the search, one of them was found in St. Nicholas Church and the other in the Church of the Assumption. This fact speaks of the relative poverty of church parishes, due to which the bells were transferred from church to church before worship. The poverty of the parishes of Zolotonosha churches is evidenced by the data given by the priest Gregory Kolomensky in the "Collection of necessary information about all parishes of the Poltava province" for 1895, where they are defined as not included in the number of parishes "relatively famous profitable." In Zolotonosha County in 1893 there were 103 churches, including 94 parish, 2 monastic, 5 cemetery. The house church was in the women's gymnasium (now the technical school building). The number of clergy was 251 people. "In the county town of Zolotonosha there are 6 churches, 3 full-time, 1 registered, 1 cemetery, 1 house." The Cathedral Church of the Assumption belonged to the deanery of Archpriest Simeon Vasilyevich Andrievsky. The churches of the villages of Voznesensky, Domontov, Dmytrivka, Kovray (Levada), Krupsky, Boguslavets, and Liplyavy belonged to the same denomination. The first documentary data about the Trinity Church, which is now located in the former suburb of Troyeschina, or Zatroits, date back to the 1840s. The building of the Trinity Church, built in 1859, was destroyed during the Soviet period. And in 2019 the newly built Trinity Church was consecrated.

Zolotonosha Zozulivsky Annunciation Monastery (XVII century) had an important religious and cultural-historical significance, when monks on the right bank of the Dnieper in the mountains founded the Ascension Monastery. On the left bank of the Dnieper near the village of Korobivka was his farmyard, where the abbot of Moshnogorsk Iosafat Rakovych in 1719 founded the Annunciation Monastery, which lasted 41 years, and in 1760 was destroyed by fire. Abbess Paraskeva asked Bishop Gervasius of Pereyaslav to give permission for the restoration of the monastery in Zolotonosha on the estate bought from Vasyl Meles. The bishop addressed a letter to the Holy Synod with the abbot and at the same time asked Hetman Kirill Rozumovsky to petition for this. In October 1761, a decree was received from the Holy Synod in the name of the Bishop of Pereyaslav, which allowed the construction of a monastery in Zolotonosha and named it Zolotonosha Annunciation Maiden. Later it was given the name Zozulivsky - from the tract Zozulivka, where he was located. After the synodal decree, the Zaporizhzhia Cossack Yakov Shcherbyna began to build a church for the monastery in the name of the Annunciation at his own expense, and in 1743 it was completed. In 1783, a refectory church was built in memory of the transfer of the relics of St. John Chrysostom. This monastery was the center of education in the region. Here even rich landowners gave their children for primary education. The students of this school, in particular, were the Tymkivsky brothers - professors, writers, public figures, and their nephew - M. Maksymovych - professor, the first rector of Kyiv University. A number of facts testify to the significance of the Annunciation Monastery. Thus, the Synod of the monastery (1777), which contains 1619 records, the family of B. Khmelnytsky is mentioned by 9 names. It is probable that the commemoration was recorded by one of the daughters of the Hetman of Ukraine. In 1818, during the renovation of the Ladynsky Monastery, the Annunciation was closed. The Church of the Annunciation became a parish church, and the nuns were transferred to the Krasnogorsk Monastery near Zolotonosha. For some time after the closure of the monastery there was a women's hermitage, where nuns lived at their own expense. In 1937 the Church of the Annunciation was destroyed, and in February 2002 the Church of the Annunciation was rebuilt in an adapted room.

The Holy Dormition Cathedral of Zolotonosha is one of the largest temples in Central Ukraine, decorating the city, making it bright and attractive. 
The history of the temple dates back to 1745 . Then, on the place where today's brick building stands, under the abbot V. Petrashevich, a Cossack from Domontovo built a wooden church of the Assumption of the Blessed Virgin. For work he took 35 rubles, in addition to provisions. "There is a wooden cathedral in it, built in 1745 in honor of the Assumption of the Blessed Virgin. This parish consists of the inhabitants of the suburb of Strunkovets with a part of the city residents" [1]. This building was built on the site of the temple, which is mentioned by Paul of Aleppo.

But the building of the Assumption Cathedral did not stand the test of time and began to collapse. The first rector of the University of Kyiv, M. Maksymovych, bypassing the church, did not find anything interesting in it for the history of Zolotonosha. And among the books he came across the unknown Kyiv edition of Trebnyk in 1708. "The old walls of the Church of the Assumption," sighed the scientist, walking on it, barely holding on and waiting for a quick renovation; but I always feel sorry when wooden church buildings are built in a new style, on the site of the old ones in the old Ukrainian style, which resembles the conical tops of Indian pagodas" [1].

In 1845, a new three-throne cathedral with thrones was built in honor of the Assumption of the Mother of God, in the name of the Apostles Peter and Paul and the holy martyrs of Faith, Hope, Love and their mother Sophia. The Holy Dormition and St. Nicholas churches had one house each, where deacons lived and taught boys to read and write. In the Clear Book of the Poltava Diocese for 1902 there is the following entry: "Cathedral-Assumption wooden church with the same bell tower on a stone foundation, cold, built in 1745, the church has a church library and church-parish school" [11].

In May 1907, "for some reason, a new wooden temple was completely destroyed in broad daylight." The ancients said that Father Simeon forgot to put out the candle on his way to the Krasnogorsk monastery. Archpriest Simeon Andrievsky, the same year began construction of a new brick church, which lasted three years, and in 1910 the Assumption Cathedral was consecrated. The church has three thrones: in honor of the Assumption of the Blessed Virgin, the Holy Trinity and St. Nicholas. Assumption Cathedral Zolotonosha has its own architectural features [9].

In the archives of the Poltava Spiritual Consistory, the project of the Holy Dormition Cathedral is not listed in the register of church projects. Most likely, it was built on a typical project. This is evidenced by other religious buildings, located in different places and similar in appearance and interior to the Zolotonosha temple. In particular, specialists in the field of architecture note the similarity of the churches of the Nativity of the Virgin Kozelshchansky convent, Holy Intercession village Antonovka Varvynsky district of Chernihiv region, Trinity in Kremenchuk, Nativity of Christ, Settlements of the distant Volga region. The style of the building, in the architectural sense, is a kind of combination of the eparchial "brick style" and the Byzantine. Scholars define it as Russian-Byzantine. Vladimir Cathedral in Kyiv was built in this style.

In 1912, the Church of the Assumption had a parish school, 52 tithes, 2 farms. History mentions the names of the clergy of the church of that period: archpriests Simeon Andrievsky, priests Adrian Sokolovsky, Mykola Rudychev, Tarasy Basenko, Vasyl Stepanchenko; deacons Stefan Milgevsky, Gregory Orlovsky, Stephen Milshievsky; psalmists Mykola Andrievsky, Oleksiy Popovych, Aristarkh Matskov; church elders Benedict Kornienko and nobleman Petro Savych; burgher Hryhoriy Voitseshko; peasant Dmitry Radchenko, Fedor Mishchenko. Gregory of Bilin, who came from an ancient family of priests, was appointed abbot in 1871 and archpriest in 1873 . From 1874 to 1889 he was a member and then chairman of the Zolotonosha district branch of the Poltava Diocesan School Council [11, 12].

Militant atheism has not escaped any church in Zolotonosha. Only the Holy Dormition survived, but the Bolsheviks tried to destroy it. In the 1930s, the Communists conducted anti-religious propaganda. The Soviet government increasingly resorted to terror against the church and the faithful. Under the pretext of organizing aid to the starving in 1921, the state carried out a large-scale seizure of church property throughout Ukraine. In 1990, the stamp "top secret" was removed and a letter from V. Lenin to V. Molotov was published, in which it was said that the jewels had been confiscated from the cathedrals for the starving [4]. It was believed that the greater the number of clergy managed to shoot, the better. When the churches in the county were closed, the surviving church items were taken to the Zolotonosha District Museum, which was constantly reorganized and changed its place of residence. In the description of the museum's property, there were mi- 
raculous icons of the Mother of God of the Krasnogorsk monastery of Dubenska and Koretska "old writing", 106 other icons. All of them were located in the old museum building in an adapted pantry in the corridor. It is obvious that among these things were the things of the Church of the Assumption. At the same time, an act was drawn up with a detailed description of the miraculous icon of the Dubna Mother of God of the Krasnogorsk Monastery, which disappeared without a trace.

The renewal affected the church life of Zolotonosha. After that authorities in Ukraine aimed to break the monolith of Orthodoxy, while playing on national liberation feelings, and actively sought to inflame an interfaith war, which, according to its plan, would turn the people away from the Church. The state has been planting and supporting "renewal" for two decades. The confiscation of churches and other premises of the canonical Church became widespread. Bishop Serhiy (Labuntsev) of Zolotonosha was also included in the initiative group for convening the Council of Ukrainian Bishops. In June 1925, a cathedral was held in Lubny, which formed the Ukrainian Cathedral-Episcopal Church (official name of the Ukrainian Orthodox Church). Sergei Labuntsev became one of its leaders.

Arbitrary closure of churches and other prayers, unwarranted interference in the internal life of religious communities caused mass discontent and, in some cases, resistance from believers. This gave rise to the March 1930 Directive of the Administrative Department of the NKVD, marked "Secret", which declared that the closure of houses of worship should be the result of appropriate political and anti-religious work.

The closing of prayer houses and the removal of bells should never be mass, and the issue of closing each prayer house should be raised and decided separately. Closed prayer rooms can be used only for cultural and educational purposes. In 1937, lists of citizens of Zolotonosha were collected with signatures on the closure of the Assumption Cathedral. The church was closed and destroyed by Komsomol members. The shrine has been turned into a salt warehouse. Traces of barbarism have not been cured even today. But the interior of the cathedral fascinates everyone with its decoration.

The thirties of the last century were extremely tragic for the Orthodox Church. This tragedy is illuminated by an icon painted on the wall of the Assumption Cathedral. It depicts 104 Holy New Martyrs of Cherkasy who accepted death for the sake of Christ's faith. Among this host of saints are 10 gold diggers: the holy martyrs Mykhailo Nechaiv, Oleksandr Chubov, Ioann Sagarda, the martyrs Dimitry Strokan, Volodymyr Tymoshenko, Iakiv Kharchenko, Ioann Kolomyets, Kyryl Kharchenko, Iosif Bon, Hryhoriy Yermolenko. The unique edition of the Cherkasy Eparchy of the Ukrainian Orthodox Church describes the righteous life and martyrdom of clergy, monks, and ordinary believers devoted to the church. All of them laid down their lives for God, for faith, were with their people, brought the world of truth to the people who expected it from them [3, 10, 13].

The repressive actions of the authorities were cruel, illegal and arbitrary. That is why the cases fabricated against the new martyrs are similar: first deprivation of the opportunity to serve the Lord, persecution, tax collection, campaigns against the "people", and then - accusations of undermining power, anti-Soviet propaganda, terrorism, forcing to renounce faith.

In September 1937, the first mass shooting of Cherkasy clergy took place: six from Zolotonosha and three from Kaniv were shot in the Cherkasy prison. Five of them: Borys Drozdovsky, Ioan Sagarda, Mykhailo Nechaiv, Oleksandr Chubov, Iosif Bon are among the new martyrs. The dramatic, miserable fates of the new martyrs, who in one way or another are involved in Zolotonosha and Zolotonosha County, evoke a deep sense of respect and reverence for those who lived on this earth, faithfully and truly served God and people.

In October 1997, the Holy Synod decided to include the New Martyrs among the holy martyrs, to establish the Day of Celebration for the Holy New Martyrs of Cherkasy on May 13/26, the day of remembrance of St. Macarius, Pereyaslav and Kaniv, to write an icon to the Holy New Martyrs.

An interesting fact was found in B. Hryvachevsky's book "Letters from Solovki", where the editor of the newspaper "Solovetsky Vesnik" said: "Little is known about Ukrainians. There are some memories. One of the women prisoners in the 1920 s gave birth to a child in the camp and was later deported to Anser Island. She mentioned the bishop of Zolotonosha, who secretly baptized her baby. After performing the rite, the priest talked for a long time with the young mother and, 
learning that she was an orphan, advised him to go to Ukraine to Zolotonosha and live in his family after his release" $[5,8]$.

This is an act of humanity of a Ukrainian who served the Lord in the harsh Solovetsky Islands.

The Ukrainian Autonomous Orthodox Church, headed by Archbishop O. Hromadsky, emerged in the ethnic Ukrainian lands seized by the German invaders. The official date of creation of this branch of Orthodoxy (August 1941) at the Council of Bishops in Pochaiv. In the same year, a directive was signed "On the understanding of church issues in the occupied regions of the Soviet Union," which stated not to hinder the intensification of the church movement, preventing its consolidation, to plant sects. In addition, the occupiers skillfully took advantage of the lack of unity in Ukrainian Orthodoxy to prevent the creation of any all-Ukrainian church structures. Therefore, the German occupation authorities supported the initiative to repair the building of the Assumption Cathedral. And in January 1942 the service was resumed [6].

The flag of the Ukrainian Cossack Hundred was consecrated during the service. The consecration was conducted by Father Gnipovsky, who called to preserve and protect this flag as a symbol of the will and struggle of the Ukrainian nation. After Zolotonosha's release, NKVD servants, according to the modern version, arrested the father. Their fate was the same as that of all the prisoners of this cruel organization.

During the difficult years of the war, people increasingly turned to religion, to God, seeking salvation and comfort. The rise of the religious feelings of the citizens, the significant role of the church in mobilizing the spiritual forces of the people forced J. Stalin and the Soviet leadership to reconsider the previous policy. In September 1943, a meeting decided to liberalize church policy. Already in 1945, there were 6,133 Orthodox churches, 15 male and 27 female monasteries, 14 bishops, 4,363 priests, 422 deacons, and 1.2 million Orthodox lay people in Ukraine. During 1941-1945, 18 churches were opened in the Zolotonosha region.

After the war, the Holy Dormition Cathedral remained in operation, but under the close supervision of law enforcement and ideological bodies. The late 1950s and early 1960s marked a new round of brutal Soviet propaganda against religion and Orthodoxy in particular. In October 1958, the resolutions of the Council of Ministers of the USSR "On Monasteries in the USSR" and "On Taxation of Profits of Enterprises of Diocesan Administrations, as well as the Profits of Monasteries" were issued. It was planned to increase land tax rates. The state fought against any manifestations of the influence of religion on public life. The ruthless ideological machine of the Communist Party formed a new community - the "Soviet people", in which there was no place for religion. Since 1959, the course "Fundamentals of Scientific Atheism" (since 1991 - the course of religious studies) has appeared in the curricula of USSR universities.

The archives of the Zolotonosha Museum of Local Lore contain documents characterizing the attitude of the state to the church and its religious buildings. In those days, priests conducted services in the temple under constant pressure, performed the rites of the sacrament of baptism at home, the rite of burial in secret. Visits to the church were monitored by the authorities, then discussed at meetings of collectives, at meetings of local trade union committees and at the bureaus of party organizations.

The collapse of communist ideology in the late 80 's-early 90 's contributed to the revival of religious life, expanding the role of the church in shaping the spirituality of Ukraine. This process was also accompanied by the restoration, restoration of old and construction of new temples.

It was in 1991 that two large bells, cast in Voronezh, were purchased for the bell tower of the Assumption Cathedral. In 1997, it was recreated almost in its original form and decorated with a mosaic icon "Savior Non-Manufactured", new crosses were installed on the baths of the temple. On Trinity in the church the singing of the cathedral choir "Resurrection" under the direction of T. Zhurba sounded. Evidence of the high performance skills of the choir is the honoring of the team with the title of "People's" (1995). Today's church choir of 12 people is unique. In 2013, a children's choir was created. There is a Sunday school at the cathedral.

Local master O. Kutenkov painted and painted inside and out. In the courtyard of the church there are icons of the Intercession of the Blessed Virgin Mary, Archangel Michael and Archangel Gabriel, decorated with a small waterfall and a fountain, flowers. A memorial sign dedicated to the $1025^{\text {th }}$ anniversary of the baptism of Kievan Rus has been erected in the square behind the church fence. 
The temple preserves the shrines, to which parishioners go with faith and hope for help. The parishioners treat the icon of the Mother of God of Korobiv with special reverence. Probably, this is an icon from the Annunciation Zozuliv Monastery, known for its miracles. The icon of the Tikhvin Mother of God, which according to the testimony also has a miraculous power, impresses with its majesty and beauty. Some parishioners say they saw the icon "crying." The parishioners pray diligently near the icon of St. Luke of the Crimea, which contains part of the shroud of the relics of the saint and his homeland.

During his life, the future Saint, and then - doctor V. Voino-Yasenetsky worked in the Zolotonosha region. In 1908 he was the Zemstvo doctor of the Dengiv Hospital. Near the altar is an icon of St. Job and Amphilochius Pochaevsky with fragments of relics. The altar houses unique editions of the Gospels in expensive salaries from different times.

With a large influx of communicants, the priests of the cathedral use a silver chalice (bowl) and a discus with coinage, gifts from the founder of the church Simeon Andrievsky. Today the Assumption Cathedral of Zolotonosha is a cathedral.

\section{Discussion}

In the conditions of socio-economic, political crises and pandemics, the vast majority of the population is in a state of social and spiritual apathy. Therefore, there is a need to find and study significant means of influencing the public consciousness to form the national identity of Ukrainians, increase the morality and spirituality of Orthodox Christians, democratization of society on the basis of Christian values. Such an effective means of influence is the development of Ukrainian Orthodoxy. It is the religiosity of modern Ukrainian society, which has a tendency to grow that is designed to increase the morality and spirituality of Orthodox Christians.

This is not sufficiently defined as a special object of study. As a rule, scientific sources consider general historical aspects of religiosity. In view of this, the historical past and the role of the Ukrainian church, temples, the spiritual life of the Ukrainian people, which was banned for 70 years, and the spiritual development of the Orthodox Christian at the local level, in our case on the example of the Temple Uspenija of the Virgin in Zolotonosha of Left-bank Dnieper.

A considerable amount of literature has been published on the problem under study, but the vast majority of it appeared by the mid-1980s and was ideologically influenced in previous years. Interpretation of certain events is presented in it within the officially permitted approaches and concepts.

The results of the study can be used by historians, political scientists and other experts to further substantiate the holistic history of Orthodox churches in Zolotonosha, the place and role of Zolotonosha Holy Dormition Cathedral, its impact on increasing the social activation of Orthodox Christians in forming the national identity of Ukrainians.

Materials and conclusions of the study can be used to create works that summarize the history of political, social, national and cultural development of Ukraine, in the preparation of scientific papers, teaching and methodological manuals, the creation of special courses on the spirituality of Orthodox Christians.

The practical significance is determined by the suitability for use in the process of modern transformation of the national identity of Ukrainians by politicians, parties, public organizations, state institutions, and the media. This will accelerate the process of development of Ukraine as a free independent state.

The historical role of churches, the spiritual development of the Orthodox Christian at the local level, and the means of influencing the improvement of the morality and spirituality of the Ukrainian people deserve further research and study.

\section{Conclusions}

1. The integral history of Orthodox churches of Zolotonosha region is investigated, as an important means of increasing social activity of the individual and social development.

2. The place of the Holy Dormition Cathedral in Zolotonosha as a historical, architectural and spiritual monument of Ukraine in the development of the spiritual culture of the Ukrainian people is substantiated. 
3. The role of the Temple Uspenija of the Virgin Mary as one of the largest temple buildings in Central Ukraine and its influence on raising the public consciousness of Orthodox Christians in the formation of national identity are revealed and proved.

\section{References}

[1] Maksymovych, M.; Hubskyi, B. V., Lytvyn, V. M., Smolii, V. A. (Eds.) (2003). Spohad pro Zolotonoshu. Cherkaskyi krai zemlia Bohdana i Tarasa. Kyiv: Ukrainski propilei, 528-539.

[2] Saharda, M.; Hubskyi, B. V., Lytvyn, V. M., Smolii, V. A. (Eds.) (2003). Misto Zolotonosha ta yoho sviati khramy. Cherkaskyi krai - zemlia Bohdana i Tarasa. Kyiv: Ukrainski propilei, 331-367.

[3] Sahan, O. N.; Smolii, V. A. et. al. (Eds.) (2003). Etsyklopediia istorii Ukrainy, Vol. 10. Bratske obiednannia parafii UAPTs. Kyiv: V-vo «Naukova dumka», 688. Available at: http://www.history.org.ua/?termin=Bratske_obiednannia

[4] Manovskyi, Yu. Yu. (2002). Cherkaska mynuvshyna. Pravoslavni monastyri na terenakh suchasnoi Cherkaskoi oblasti pislia 1917 roku. Book 2. Cherkasy: Vidlunnia, 480.

[5] Mykhailychenko, H., Pyliavets, L., Prelovska, I. (1999). Pershyi Vseukrainskyi pravoslavnyi tserkovnyi sobor UAPTs 14-30 zhovtnia 1921 r. Kyiv-Lviv, 564.

[6] Pocheptsov, V., Pocheptsova, Ye. (2009). Nash krai uroky Druhoi svitovoi viiny. Cherkasy, 116.

[7] Zharkykh, M. (2013). Pavlo Khalebskyi. Available at: http://chtyvo.org.ua/authors/Zharkykh_Mykola/Pavlo_Khalebskyi/

[8] Kryvosheia, V. V. (2013). Sehment synodykiv rokovoi pamiati v monastyrskykh i tserkovnykh synodykakh. Natsionalna ta istorychna pamiat. Kyiv: «NVTs «Priorytety», 6, 293.

[9] Hazeta «Zolotonoshskyi holos» (1910).

[10] Sofronii (Ed.) (2001). Sviati novomuchenyky i spovidnyky Cherkaski: zhyttia, podvyhy, strazhdannia. Cherkasy: Vydannia Cherkaskoi yeparkhii Ukrainskoi Pravoslavnoi Tserkvy, 400.

[11] Spravochnaia klyrovaia knyha po Poltavski eparkhyy za 1912 hod (1912). Poltava, XCII, 303.

[12] Sokhan, P. S. et. al. (Eds.) (1989). Opysy Kyivskoho namisnytstva 70-80-kh rokiv XVIII st. Kyiv: Naukova dumka, 389.

[13] Eismont, V. (2003). Blahovishchenskyi ostriv. Zlatokrai. 